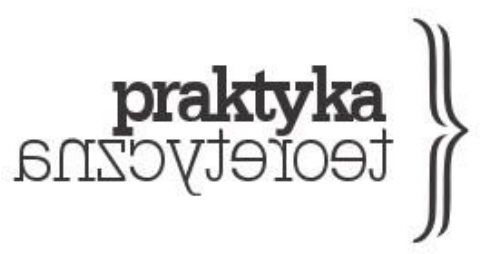

ISSN 2081-8130

DOI: $10.14746 /$ prt.2018.2.5 www.praktykateoretyczna.pl

\title{
REALIZM W PSYCHOANALIZIE
}

\author{
ALENKA ZUPANČIČ
}

PRZEŁOŻYLI: PIOTR SKALSKI I BARTOSZ WÓJCIK

\begin{abstract}
Abstrakt: Wiele spośród ostatnich dyskusji filozoficznych naznaczył, w taki czy inny sposób, oszałamiający pod niejednym względem powrót do problematyki realizmu, zainicjowany przez książkę Quentina Meillassoux Après la finitude (2006) i kontynuowany przez szerszy, choć niejednolity ruch „spekulatywnego realizmu”. Artykuł podnosi kwestię czy ta debata dotyka w jakiś sposób, a jeśli tak to w jaki, konceptualnego pola psychoanalizy lacanowskiej. Główne rozważania dotyczą statusu "realności" w nauce i jej znaczenia dla psychoanalizy w świetle lacanowskiego utożsamienia podmiotu nieświadomości z podmiotem (galilejskiej) nauki. Poważnie traktując słowa Lacana, "Jasne jest w każdym razie, że nie jestem nominalistą", artykuł próbuje zarysować psychoanalityczną wersję realizmu.
\end{abstract}

Słowa kluczowe: dyskurs, niemożliwość, Lacan, Realne, nauka, prawda. 
Wiele spośród ostatnich dyskusji filozoficznych naznaczył, w taki czy inny sposób, oszałamiający pod niejednym względem powrót do problematyki realizmu, zainicjowany przez książkę Quentina Meillassoux Après la finitude (2006) i kontynuowany przez szerszy, choć niejednolity ruch „spekulatywnego realizmu”. I rzeczywiście, wydaje się, że jesteśmy świadkami wielkiego ożywienia tej problematyki, która proponuje nowe konceptualizacje i definicje zarówno realizmu, jak i jego adwersarza („,korelacjonizmu” wchodzącego w miejsce nominalizmu). Zamierzam w tym kontekście zapytać, czy ta debata dotyka w jakiś sposób, a jeśli tak to w jaki, konceptualnego pola Lacanowskiej psychoanalizy. Z uwagi na to, że Realne stanowi jedno z centralnych pojęć tej teorii, powstaje pytanie o jego status, tym bardziej że Lacan wiąże je $\mathrm{z}$ tym, co niemożliwe. Na czym miałby polegać ten raczej dziwny realizm, który utożsamia Realne z niemożliwym?

Przypomnę krótko podstawowy argument Meillassoux. Polega on na pokazaniu, że filozofia postkartezjańska (poczynając od Kanta) odrzucała lub dyskwalifikowała możliwość osiągnięcia przez nas dostępu do bytu, który nie byłby skorelowany z myśleniem. Nie tylko nigdy nie mamy do czynienia z przedmiotem samym w sobie, niezależnie od jego związku z podmiotem, ale też nie istnieje żaden podmiot, który nie pozostawałby zawsze-już w związku z jakimś przedmiotem. Dowolny przedmiot i podmiot wyprzedzane są więc przez relację, która jest wcześniejsza od wiązanych przez siebie terminów i sama staje się głównym przedmiotem filozoficznego namysłu. Wszystkie współczesne (postkartezjańskie) filozofie sa różnymi filozofiami korelacji. Jak pisze Meillassoux:

\footnotetext{
Ogólnie biorąc, „krokiem tańca” nowożytności jest taka właśnie wiara w prymat relacji przez związanymi nią członami; wiara w konstytutywną moc wzajemnej relacji. Głównym pierwiastkiem filozofii nowożytnej, jej prawdziwym „wzorem chemicznym”, jest przedrostek „ko-”, „,współ-” (jak w ko-relacji, współ-daniu, współpierwotności, współ-obecności itd.). Można by powiedzieć, że przed Kantem jednym z głównych problemów filozofii był namysł nad substancja, natomiast po Kancie chodzi raczej o namysł nad korelacja. Przed transcendentalizmem do pytań decydujących o werdykcie $\mathrm{w}$ rywalizacji filozofów należało pytanie: który z nich poznaje prawdziwą substancję - czy to filozof poznający myślą Ideę, czy ten, który poznaje myśla jednostkę, atom, Boga - jakiego Boga? Po Kancie i od czasu Kanta rywalizację filozofów rozstrzyga się, pytając już nie o to, który poznał prawdziwą substancjalność, lecz o to, który poznał najbardziej źródłową korelację. Czy to badacz korelacji podmiot-przedmiot, korelacji noetyczno-noematycznej, korelacji językodniesienie? (Meillassoux 2015, 17-18).
}

Niewystarczalność tego stanowiska ujawnia się zdaniem Meillassoux w konfrontacji z „twierdzeniami ancenstralnymi” albo „praskamielinami”, które stanowia produkt dzisiejszej nauki eksperymentalnej i dotyczą zdarzeń sprzed powstania życia i świadomości (np. „Ziemia 
powstała 4,56 miliarda lat temu"). Podnoszą one prosty, lecz zdaniem Meillassoux nierozwiązalny dla korelacjonisty problem: jak pojąć znaczenie twierdzeń naukowych wypowiadających się wprost o takich manifestacjach świata, które są uprzednie względem powstania myśli, a nawet życia - uprzednie wobec każdej formy ludzkiej relacji z owym światem? Z korelacjonistycznego punktu widzenia twierdzenia te są, ściśle rzecz biorąc, pozbawione sensu.

Jedną z wielkich zalet książki Meillassoux jest to, że (ponownie) podjęła nie tyle kwestię związku między filozofią i nauką, ile tego, czy mówią one o tym samym świecie. Alain Badiou udzielił ostatnio odpowiedzi na podobne pytanie w kontekście polityki: „Istnieje tylko jeden świat”. Ale pytanie to odnosi się również do relacji między epistemologią lub nauką i ontologia. Może się bowiem wydawać, że nauka i filozofia rozwijają się już od pewnego czasu w światach wobec siebie równoległych: w jednym z nich możliwe jest wypowiadanie się o realności samej w sobie, niezależnie od jej związku z podmiotem, podczas gdy w drugim ten rodzaj dyskursu jest, ściśle rzecz biorąc, pozbawiony sensu. Co więc otrzymujemy po zastosowaniu do tej sytuacji aksjomatu głoszącego, że „istnieje tylko jeden świat”? Zamiast obrać częściej uczęszczaną (przez filozofię) ścieżkę, a zatem oddać się krytykowaniu nauki za brak refleksji na temat własnego dyskursu, Meillassoux wybiera inna drogę: fakt, że pewne naukowe twierdzenia wymykaja się filozoficznemu „horyzontowi sensu", wskazuje, że to z nim jest coś nie tak. Stanowisko to utrzymuje, że filozofia, aby zapewnić sobie własne przetrwanie jako praktyki dyskursywnej (można by też powiedzieć: aby zapewnić kontynuację metafizyki za pomoca innych środków), poświęciła stanowczo zbyt wiele, a mianowicie realność w jej absolutnym sensie.

Być może powinniśmy jednak podkreślić, że ta rzadziej uczęszczana droga staje się we współczesnej filozofii swoistym trendem, a Meillassoux wpisuje się weń wraz z kilkorgiem autorów o bardzo odmiennych inspiracjach. Wspomnijmy tylko o filozoficznym materializmie Catherine Malabou, której zamiarem jest rozwinięcie nowej teorii podmiotowości opartej na naukach kognitywnych. W swoich polemikach z Freudowską i Lacanowska psychoanaliza przeciwstawia ona „libidinalnej nieświadomości”, zawsze już zapośredniczonej w dyskursie, „nieświadomość cerebralną” (autoafektywność mózgu) jako prawdziwa, materialistyczna nieświadomość (Malabou 2007). Jeżeli jednak materializm Malabou zmierza ku „naturalizacji elementu dyskursywnego”, albo, mówiąc precyzyjniej, jeśli jest próbą zmniejszenia luki między elementem organicznym i podmiotem, która ma na celu odnalezienie organicznych źródeł podmiotu1, Meillassoux obiera tę samą drogę, ale porusza

1 Dlatego Slavoj Žižek ma rację, wskazując, że kosztem tego rodzaju materializmu może być ponowne uduchowienie materii (zob. Žižek 2010, 303). Nie trzeba wszelako tłumaczyć, że nasze pobieżne przywołanie Malabou nie oddaje sprawiedliwości jej argumentacji, zarówno w całości, jak i w najcenniejszych kwestiach, które podnosi. 
się w przeciwnym kierunku, a mianowicie w stronę dyskursywności natury, chociaż nie dociera do jej końca. Jego realistyczna ontologia, odróżniając od siebie pierwotne i wtórne jakości bytu, nie twierdzi, że byt jest ze swojej istoty matematyczny; twierdzi, że jest absolutny, że jest niezależny od jakiejkolwiek relacji do podmiotu, chociaż tylko w tym wymiarze, który można sformułować matematycznie. Meillassoux utrzymuje więc istnienie pewnej luki albo przeskoku (między bytem i jego matematyzacja), lecz się do nich nie odnosi. Możliwość matematycznego sformułowania pewnych jakości jest gwarancją ich absolutnego charakteru (tego, że są realne w mocnym sensie tego słowa). Realizm Meillassoux nie jest więc realizmem uniwersaliów, lecz - paradoksalnie - realizmem korelatu uniwersaliów, o którym mówi również jako o „przedmiocie odniesienia”:

\begin{abstract}
Twierdzenia, ogólnie rzecz biorąc, o tyle mają charakter idealny, że są rzeczywistością znacząca, lecz ich możliwe przedmioty odniesienia nie są z konieczności idealne (kot na słomiance jest realny, mimo że idealne jest twierdzenie: „Kot jest na słomiance”). W tym wypadku powiemy zatem: 4,56 miliarda lat temu istniały przedmioty odniesienia twierdzeń dotyczących dat, rozległości itd. takie, jakimi opisuja je te twierdzenia - ale nie same te twierdzenia, one bowiem są nam współczesne (Meillassoux 2015, 27).
\end{abstract}

Wydaje się, że nie ma sposobu na obejście faktu, że kryterium absolutu stanowi jego korelacja z matematyka. Niekoniecznie implikuje to coś subiektywnego albo subiektywnie zapośredniczonego, lecz z pewnościa implikuje coś dyskursywnego. I tu dochodzimy do sedna problemu z konceptualizacjami Meillassoux, a jednocześnie tego, co jest w nich najciekawsze. Podkreślam to w opozycji do innego wymiaru jego gestu, tego, który został tak entuzjastycznie przyjęty przez nasz Zeitgeist, chociaż ma niewielka wartość filozoficzną (lub naukowa) i jest oparty na wolnych skojarzeniach z mniej lub bardziej jasnymi odczuciami związanymi z aktualnym Unbehagen in der Kultur. Nazwijmy go wymiarem psychologicznym, który można podsumować poprzez przywołanie następującej opowieści: Po Kartezjuszu utraciliśmy wielkie zewnętrze, absolut, Realne i staliśmy się więźniami naszej własnej subiektywnej bądź dyskursywnej klatki. Jedyne zewnętrze, z jakim mamy do czynienia, to zewnętrze założone lub ustanowione przez nas lub przez różne praktyki dyskursywne. I w więzieniu tym rośnie dyskomfort, klaustrofobia, ciąła obsesja na naszym własnym punkcie, niemożność wyjścia $\mathrm{z}$ tego zewnętrznego wnętrza, jakie sobie w ten sposób zbudowaliśmy. Wkracza tu także dyskomfort polityczny, uczucie frustrującej impotencji, niemożności zmiany czegokolwiek, przesiąknięcia małymi i wielkimi rozczarowaniami niedawnej i nieco dalszej historii. Stąd pewien dodatkowy, zbawienny urok projektu, który obiecuje ponowne przedostanie się do wielkiego Zewnętrza, ponowne ustanowienie Realnego w jego absolutnym wymiarze i ontologiczne ugruntowanie możliwości radykalnej zmiany. 
Ale kluczowy aspekt propozycji Meillassoux leży zupełnie gdzie indziej niż w powyższej opowieści, która znalazła w nim (może nie do końca bez jego winy) oparcie dla pewnej fantazji, mianowicie fantazji na temat owego „wielkiego Zewnętrza”, które nas ocali ale ostatecznie przed czym? Przed tym małym, lecz irytującym kawałkiem zewnętrza, które uparcie nam dokucza, tu i teraz, uniemożliwiając jakiejkolwiek „klatce dyskursywnej” bezpieczne zamknięcie się w sobie. Innymi słowy, uznanie wielkiego Zewnętrza za fantazję nie oznacza, że jest to fantazja o Realnym, które naprawdę nie istnieje; implikuje raczej, że jest to fantazja w ścisłym znaczeniu psychoanalitycznym: ekran przesłaniający fakt, że rzeczywistość dyskursywna jest nieszczelna, sprzeczna i splątana z Realnym, które jest jej nieodzowną druga stroną. To znaczy: wielkie Zewnętrze jest fantazja zakrywająca Realne, które jest już tu obecne.

Sedno projektu Meillassoux nie polega na przeciwstawianiu elementu realnego elementowi dyskursywnemu i na marzeniu o wyrwaniu się poza dyskursywność; przeciwnie, sednem jego projektu jest ich powiązanie, które mogłoby wymknąć się logice transcendentalnej konstytucji, a zatem uciec od ich współzależności. Powiązanie to opiera się na dwóch fundamentalnych twierdzeniach: wspomnianej już tezie o możliwej matematyzacji jakości pierwotnych oraz tezie o absolutnie koniecznym charakterze przygodności. Nie trzeba dodawać, że obie tezy są filozoficzne i mają na celu położenie fundamentu pod to, co wydaje się po prostu założeniem współczesnej nauki - chodzi tu o wspomniane powiązanie elementu dyskursywnego i realnego. Mogłoby się zdawać, że próbują one dokonać korekty naiwnego realizmu nauki, zastępując go refleksyjnym, filozoficznie ugruntowanym realizmem „spekulatywnym”.

Ale tutaj pojawia się pierwsze naprawdę interesujące pytanie: jaki jest właściwie status realizmu, który jest zakładany przez operacje nauki? Czy jest to po prostu jakaś forma realizmu naiwnego, prostego przekonania, że opisywana przyroda jest absolutna $\mathrm{i}$ istnieje niezależnie od nas? Wyjściowe założenie Meillassoux rzeczywiście wydaje się głosić, że nauka działa w sposób właściwy, ale nie posiada własnej ontologicznej teorii, która odpowiadałaby jej praktyce. Biorąc pod uwagę ramę jego projektu, rzeczywiście uderza nas, jak mało czasu filozof ten poświęca omówieniu współczesnej nauki, jej podstaw lub wyjściowego gestu, założeń i następstw - czyli omówieniu tego, co nauka rzeczywiście robi. W kontrze do tego możemy powiedzieć, że Lacan posiada nadzwyczaj dobrze opracowaną teorię nowoczesnej nauki i jej wyjściowego gestu (do pewnego stopnia teoria ta jest częścia szerszej strukturalistycznej teorii nauki), w odniesieniu do której sytuuje on własny dyskurs psychoanalityczny. I tu właśnie trzeba rozpocząć. Związek między dyskursem psychoanalitycznym i nauką jest kluczową kwestią w całym dorobku Lacana, choć nie jest to w żadnej mierze prosta sprawa. $Z$ jednej strony Lacan zakłada ich absolutne pokrewieństwo i współczesność (co potwierdzaja niezliczone zdania typu „podmiot 
nieświadomości jest podmiotem nowoczesnej nauki”, „psychoanalizę umożliwiło to samo cięcie, które zainaugurowało nowoczesną naukę”...). Z drugiej strony istnieje nie mniej ważna różnica i dysonans między psychoanalizą i nauką, czego najistotniejszym wskaźnikiem jest pojęcie prawdy, które uwzględnia różnicę między odpowiadającymi im „obiektami”. W skrócie: wspólny grunt psychoanalizy i nauki to realność w jej absolutnym wymiarze, lecz psychoanaliza i nauka tropią tę realność na różne sposoby.

Czym jest Lacanowska teoria nauki? Lorenzo Chiesa (2010, 159-177) podją niedawno ten temat i nadał mu odpowiednie znaczenie w kontekście podobnej debaty i prac Jean-Claude’a Milnera (to dzięki Chiesie biorę udział w tej dyskusji). Zgodnie z tą teorią galileizm zastapił dawne pojęcie natury pojęciem nowoczesnym, zgodnie z którym natura jest tylko empirycznym przedmiotem nauki. Formalnym warunkiem tej zmiany jest pełna matematyzacja nauki. Innymi słowy, po Galileuszu „natura nie posiada żadnej innej substancji zmysłowej niż to, co jest konieczne dla prawidłowego funkcjonowania matematycznych formuł nauki” (Milner 2008, 287-288). Wyrażając to nawet mocniej: rewolucja galileuszowa w nauce polega na wytworzeniu swojego obiektu („natury”) jako własnego obiektywnego korelatu. U Lacana możemy znaleźć całą serię tego typu bardzo mocnych konstatacji, na przykład: „Energia nie jest substancja [...], jest stała liczbową, którą fizyk musi odnaleźć w swoich kalkulacjach, by móc w ogóle pracować” (Lacan 1990, 18). Fakt, że nauka mówi o takim czy innym prawie natury i o wszechświecie, nie znaczy, że zachowuje perspektywę wielkiego Zewnętrza (które miałoby nie podlegać żadnej dyskursywnej konstytucji), jest raczej odwrotnie. Nowoczesna nauka rozpoczyna się od wytworzenia własnego przedmiotu. Nie należy tego rozumieć w Kantowskim sensie transcendentalnej konstytucji zjawisk, lecz w nieco innym, mocniejszym sensie.

Nowoczesna nauka dosłownie stwarza pewną nową realność/rzeczywistość; rzecz nie w tym, że przedmiot nauki jest „zapośredniczony” przez jej formuły, lecz że jest od nich nieodróżnialny; nie istnieje poza nimi, a mimo to jest realny. Wywołuje realne skutki albo skutki w realności. Precyzując: nowa realność, która powstaje wraz z rewolucją naukową Galileusza (pełną matematyzacja przyrody), charakteryzuje się tym, że - i to ma decydujące znaczenie - (naukowy) dyskurs wywołuje w niej skutki. $\mathrm{Na}$ przykład lądowanie na księżycu. Gdyż fakt, że dyskurs ten wywołuje skutki w realności, nie stosuje się do natury w szerokim i luźnym sensie tego słowa, a tylko do natury jako fizyki lub dla natury fizycznej. Ale zawsze pozostaje też, mówi Lacan:

argument realistyczny. Nie możemy oprzeć się myśli, że natura istnieje niezależnie od naszego istnienia, nas i naszej nauki, tak jakby nauka należała do nas, a nie określała nas. Oczywiście nie będę tego kwestionował. Natura istnieje. Ale od fizyki odróżnia ją to, że o fizyce warto coś mówić i że dyskurs wywołuje w niej skutki, podczas gdy każdy wie, że żaden dyskurs nie wywołuje żadnych skutków w naturze, 
dlatego zresztą skłaniamy się do darzenia jej taką miłością. Bycie filozofem przyrody nie było nigdy uważane za dowód materializmu ani jakości naukowej (Lacan 2006a, 33).

W tym gęstym i rozstrzygającym cytacie kluczowe są trzy sprawy: 1) Przesunięcie akcentu z dyskursywnego badania realności na skutki dyskursu w realności; związana z tym 2) definicja nowo powstałej rzeczywistości; oraz 3) problem materializmu. Zatrzymajmy się krótko przy trzecim punkcie, który poruszyliśmy już przy okazji kwestii „,nieświadomości cerebralnej”. Wchodzi tu w grę zasadniczy element możliwej definicji materializmu, który sformułować by można następująco: materializmu nie gwarantuje żadna materia. Do prawdziwego materializmu nie prowadzi przywołanie materii jako ostatecznej substancji, z której wszystko powstaje (i która zyskuje często w tej perspektywie konceptualnej charakter w wysokim stopniu duchowy). Prawdziwy materializm, który - jak z uderzająca bezpośredniością stwierdza Lacan w innym ważnym fragmencie - może być tylko materializmem dialektycznym2, ugruntowany jest nie w prymacie materii ani w materii jako pierwszej zasadzie, ale w idei konfliktu, rozłamu i powstałej w nim „paralaksy realności”. Innymi słowy, podstawowy aksjomat materializmu nie głosi, że „materia jest wszystkim” albo „materia jest pierwotna”, lecz odwołuje się do pierwotnego charakteru cięcia. Niesie to oczywiście określone konsekwencje dla realizmu, który należy do tej formy materializmu.

Kieruje to nas z powrotem ku punktom 1) i 2), które możemy omówić łącznie, gdyż dotyczą dwóch aspektów tego nowego, „dialektycznie materialistycznego” realizmu. Logika, jaką stosuje Lacan, odróżniając naturę i fizykę, nie polega na odróżnieniu natury jako niedostępnej rzeczy samej w sobie i fizyki jako natury o transcendentalnej strukturze, do której nasza wiedza ma dostęp. Jego teza jest inna i bardziej radykalna. Nowoczesna nauka, która stanowi ostatecznie możliwe do historycznego zlokalizowania wydarzenie, stwarza nowa przestrzeń realności albo realność jako nowy wymiar („naturalnej”) przestrzeni. Fizyka nie „obejmuje” natury (nie dokonuje też jej symbolicznego podwojenia), lecz jest do niej dodana, podczas gdy przyroda pozostaje tam, gdzie zawsze była. „Fizyka nie jest czymś rozciąającym się, jak dobroć Boga, na cała naturę" (Lacan 2006b, 34). Przyroda pozostaje na swoim miejscu nie jako niezgłębione Realne samo w sobie, lecz jako Wyobrażeniowe, które możemy widzieć, lubić i kochać, lecz które jest zarazem dość mało istotne. Istnieje zabawna anegdota, która opowiada, jak przyjaciele Hegla zaciagnęli go

\footnotetext{
2 „Jasne jest w każdym razie, że nie jestem nominalistą. Moim punktem wyjścia nie jest teza, że nazwa to coś, co zwyczajnie doczepia się do realności. A coś trzeba wybrać. Jeżeli jesteśmy nominalistami, to musimy całkowicie odrzucić materializm dialektyczny, więc mówiąc krótko, wybór tradycji nominalistycznej, która jest, ściśle rzecz biorąc, jedynym zagrożeniem idealizmu dla dyskursu takiego jak mój, jest oczywiście wykluczony. Nie chodzi o bycie realista w takim sensie, w jakim było się realistą w średniowieczu, czyli w sensie realizmu uniwersaliów; w grę wchodzi zwrócenie uwagi na to, że nasz dyskurs, nasz dyskurs naukowy, odnajduje realność tylko poprzez zależność od funkcji pozoru" (Lacan 2006b, 28).
} 
do Alp, by uświadomił sobie i zachwycił się uderzającym pięknem tamtejszej przyrody. Wszystko, co Hegel miał powiedzieć na temat ukazującego mu się wzniosłego spektaklu to: Es ist so. Lacanowi bardzo by się to spodobało. Es ist so - nic więcej do dodania na temat gór. Nie dlatego, że nie możemy ich naprawdę zrozumieć, lecz dlatego, że nie ma tu nic do zrozumienia. (Jeśli mówimy, że wiek tego oto kamienia jest taki bądź inny, to mówimy o innej rzeczywistości - tej, w której istnieją skutki dyskursu.)

Podana przez Lacana definicja tej różnicy jest w rzeczy samej niezwykle zwięzła i precyzyjna. W gre wchodzi nie to, że natura jako obiekt naukowy (czyli jako fizyka) jest tylko efektem dyskursu, jego skutkiem - i że w tym sensie fizyka nie ma naprawdę do czynienia z realnością, lecz tylko z własnymi konstrukcjami. W grę wchodzi raczej to, że dyskurs nauki stwarza, otwiera przestrzeń, w której dyskurs ten ma (realne) skutki. A to wcale nie to samo. Mamy tu do czynienia z czymś, co bardzo dosłownie, od wewnątrz, dzieli świat na dwoje.

Fakt, że dyskurs nauki stwarza, otwiera przestrzeń, w której ten dyskurs wywołuje (realne) skutki, znaczy także, że może on tworzyć coś, co nie tylko staje się częścią rzeczywistości, lecz może także ją zmienić. „Dyskurs naukowy potrafił doprowadzić do lądowania na księżycu, gdzie myśl jest świadkiem wtargnięcia pewnej realności, przy użyciu matematyki, której jedynym aparatem jest aparat językowy" (Lacan 1990, 36). Lacan dodaje, że owo wtargnięcie realności nastąpiło „nie wywołując w filozofii poruszenia u filozofów". Możemy chyba potraktować tę uwage jako problematyzację pewnego aspektu współczesnej filozofii, która ma tendencję do pomijania kluczowego wymiaru nauki właśnie w tym punkcie realności, który jest przez nią sprowadzany do logiki „rozumu instrumentalnego”, „technicyzmu” itd. Możemy tu też dostrzec aluzję do współczesnego powiązania filozofii z „dyskursem uniwersyteckim”, który można by najkrócej zdefiniować jako więź społeczną, w której dyskurs nie wywołuje skutków.

Wracając do punktu wyjścia tej dygresji, diagnoza Lacana na temat realizmu w nauce może być podsumowana następująco. Chociaż realizm naiwny stanowi być może spontaniczną ideologię wielu naukowców, jest to całkowicie nieistotne dla konstytucji dyskursu naukowego, jego skuteczności i sposobu działania. Jak już widzieliśmy, oznacza to, że nowoczesna nauka dotarła do absolutnego charakteru swojego przedmiotu odniesienia nie poprzez oparcie swoich sądów na założeniach realizmu naiwnego, czyli naiwnie zakładając istnienie tego przedmiotu „w naturze”, lecz za sprawą zredukowania go do litery, która jako jedyna otwiera przestrzeń realnych skutków dyskursu (naukowego). I nie należy tego rozumieć jako „redukowania” bogactwa jakości zmysłowych do absolutnego minimum, które zapewniałoby jednak ciagłość tej samej substancji. Redukcję tę powinniśmy rozumieć jako cięcie i substytucję. Nie chodzi też o klasyczną logikę przedstawienia: litera nie przedstawia jakiegoś aspektu natury zmysłowej, lecz dosłownie ja zastępuje. I robi to za pomocą czegoś, co należy do dyskursu (do pozoru), ale co może - właśnie dlatego, że 
należy do dyskursu - zmierzać w kierunku realności. Pozwala to nam wrócić do postawionej wcześniej kwestii: „Warto mówić tylko o realności, w której sam dyskurs wywołuje skutki” (Lacan 2006a, 31). Argument ten nie głosi, że realność jest tylko efektem dyskursu. Związek między dyskursywnością i realnością (do którego odnosi się Meillassoux w polemice ze współczesnym obskurantyzmem3) znajduje tu znacznie mocniejszą podstawę niż wtedy, gdy twierdzi się po prostu, że przedmiot odniesienia („,obiekt naturalny”) jest absolutny jedynie w swoim matematyzowalnym aspekcie. Meillassoux nie postrzega matematyzacji nauk jako cięcia w rzeczywistości, które (tylko) wytwarza wymiar realności, ale jako najdalszy punkt kontinuum, ciagłego wyostrzania sposobów, w jakich naukowcy mówią o rzeczywistości; w jego wypadku realność odnosi się do czysto formalnej/formalizowalnej cząstki rzeczy tkwiącej ostatecznie w sieci wyostrzonych form wypowiedzi naukowych. Powtórzmy: „4,56 miliarda lat temu istniały przedmioty odniesienia twierdzeń dotyczących dat, rozległości itd. takie, jakimi opisuja je te twierdzenia - ale nie same te twierdzenia, one bowiem sa nam współczesne”. Idealny charakter naukowej formuły chwyta w swoją sieć, tu i teraz, fragment rzeczy, która w samej sobie jest absolutna (to znaczy istniała niezależnie od tej sieci 4,5 miliarda lat temu). Albo, ujmując to w inny sposób: realność jest tą częścią substancji, która nie tyle prześlizguje się przez sieć matematyzowalnej nauki, co zostaje przez nią uchwycona. Natomiast metafora Lacanowska, a wraz $z$ nia cała rozwijana przez francuskiego psychoanalityka perspektywa, jest nieco inna: realności nie gwarantuje już spoistość liczb (czy liter), ale niemożliwość, czyli ograniczenie ich spoistości. Dlatego nauka operuje, nie tyle chwytając w swoją sieć realność jako absolutny przedmiot, co raczej dotykając realności za sprawą wzajemnego nakładania się na siebie dziur występujących w jej sieci i dziur występujących w rzeczywistości. Jeśli nie warto mówić o realności czy Naturze poza dyskursem, to dlatego, że z konieczności pozostajemy na poziomie pozoru, a więc możemy powiedzieć cokolwiek chcemy. Na realność wskazuje z kolei fakt, że nie wszystko jest możliwe. W tym miejscu pojawia się inny ważny komponent Lacanowskiej realności, który łączy realizm skutków z modalnością niemożliwości. Można by wyrazić to następująco: coś wywołuje skutki, jeśli nie może być czymkolwiek (to znaczy, jeśli jest niemożliwe w jednym ze swoich własnych segmentów).

Artykulacja, a mam przez to na uwadze artykulację algebraiczna, pozoru - w której chodzi o same litery - i jej efektów: oto jedyny aparat pozwalający nam wskazywać to, co jest realne. Realne jest to, co dziurawi pozór, ów artykułowany pozór, jakim jest dyskurs naukowy. Dyskurs naukowy postępuje, nie troszcząc się nawet o to, czy jest

Jego argument przekonuje, że filozofia korelacjonistyczna, właśnie dlatego, że głosi niemożność poznania rzeczy samych $\mathrm{w}$ sobie, zmusza nas do przyjęcia, przynajmniej potencjalnie, nawet najbardziej irracjonalnych i obskuranckich nonsensów , które są wypowiadane na ich temat. 
pozorem. Chodzi po prostu o to, by jego sieć, jego siatka - lattice, jak powiedzieliby niektórzy - pozwalała odpowiednim dziurom pojawiać się w odpowiednim miejscu. Jego jedynym przedmiotem odniesienia jest niemożliwość, do której doprowadzaja jego dedukcje. Ta niemożliwość - to realność. W fizyce dążymy do realności tylko za pomocą aparatu dyskursywnego, który napotyka ściśle granice własnej spoistości. Ale tym, co nas interesuje, jest pole prawdy (Lacan 2006b, 28).

W tym „psychoanalitycznym realizmie” absolutnie kluczowe znaczenie ma to, że realność nie jest substancja ani bytem, ale właśnie ich ograniczeniem. Innymi słowy, realność jest tym, co tradycyjna ontologia musiała odciąć, aby mogła mówić o „bycie jako bycie”. Docieramy do bytu jako bytu, tylko coś od niego odejmując - a tym czymś jest „dziura”, czyli to, czego brakuje bytowi, aby w pełni ukonstytuował się jako byt. Strefa realności jest interwałem wewnątrz samego bytu, z powodu którego żaden byt nie jest „bytem jako bytem”, bo może być, tylko będąc czymś innym, niż jest. Oczywiście można zapytać, dlaczego ma znaczenie odcięcie czegoś, czego i tak nie było? Otóż ma znaczenie, nie tylko dlatego, że po odcięciu staje się czymś, ale także dlatego, że właśnie to coś okazuje się właściwym obiektem psychoanalizy.

Nawiązując do wcześniejszej dyskusji, możemy zauważyć, że: zakrzywienie przestrzeni, które konstytuuje wymiar realności, ma swoją przyczynę i skutek. Jego przyczyną jest wyłonienie się czystego znaczącego, skutkiem zaś pojawienie się nowego rodzaju obiektu. Należy jednak spostrzec, że nie ma czegoś takiego, jak czysty znaczący, ponieważ im czystsze, im przejrzystsze jest jego cięcie, tym bardziej namacalny i nieredukowalny - lub po prostu realny - jest obiekt, który ono wytwarza. Taka fundamentalna lekcja płynie, na przykład, z psychoanalitycznego pojęcia Verneinung, negacji.

Esej Freuda pod tym tytułem jest jednym z jego najbardziej interesujących i zawiłych tekstów; konfrontuje się ze znaczącym par excellence, „nie” albo negacją. I jeśli „,czasami cygaro jest tylko cygarem”, jak miał kiedyś powiedzieć Freud, to wedle tego artykułu „nie” nigdy nie znaczy tylko „nie”, a im bardziej „instrumentalnie” go używamy (czyli im bardziej funkcjonuje jako czysty znaczący), tym bardziej prawdopodobne jest, że zaczepi się na nim coś innego. Najbardziej znany przykład Freuda to oczywiście następująca wymiana: „Pytasz kim może być ta osoba we śnie. To nie jest moja matka [Die Mutter ist es nicht]". W tym wypadku, dodaje Freud, zagadka jest rozwiązana, możemy być pewni, że to właśnie ona. Jednak gdy podążamy dalej za jego argumentem, to staje się coraz bardziej jasne, że negacja ta wprowadza coś wykraczającego poza alternatywę: „To jest moja matka”/,To nie jest moja matka". Prześledźmy ten wywód krok po kroku. Pacjent bez uprzedniego pytania o to, kto pojawił się w jego śnie, sam wyrywa się do odpowiedzi i wypowiada, opatrzone negacja, słowo „matka”. Tak jakby musiał to powiedzieć, a jednocześnie nie mógł - imperatyw miesza się tu z niemożliwością. W rezultacie słowo jest wypowiedziane jako zaprzeczone, 
a wyparcie współistnieje z rzecza, o której świadomie się mówi. Pierwszy błąd, którego należy się tu wystrzegać, polega na dochodzeniu do tego, co analizowana osoba rzeczywiście zobaczyła w swoim śnie, okłamując w swojej relacji analityka z powodu nałożonej na siebie świadomej cenzury. Tym, co nieświadome w powyższym przypadku - i jest to kluczowe nie tylko dla zrozumienia Verneinung, ale i Freudowskiej nieświadomości jako takiej - jest przede wszystkim sama cenzura, a nie po prostu jej obiekt, „matka”. Ta natomiast jest w pełni obecna w wypowiedzi, wprowadzona zreszta przez sam podmiot, który równie dobrze mógłby w ogóle o niej nie wspomnieć. Nieświadomość wiąże się tutaj z samym zniekształceniem (negacja), a nie ukrywa się w tym, co podmiot mógł rzeczywiście widzieć w swoim śnie. We śnie równie dobrze mogła pojawić się inna - znana bądź nieznana - osoba, ale nie ma to znaczenia, ponieważ opowieść nieświadomości, która interesuje psychoanalizę, zaczyna się wraz ze słowami „nie moja matka”. Sprawy staja się jeszcze bardziej interesujące, gdyż dla Freuda, nawet jeśli podczas analizy osoba ta zrezygnuje $z$ „nie” i zaakceptuje treść tego, co wyparte, to „sam proces wyparcia nie zostanie tym samym zlikwidowany” (Freud 2009, 300). Wyparcie i jego symptomy trwaja nawet po tym, jak analizowana osoba uświadomi sobie to, co wyparte, co można też sformułować następująco: możemy co prawda zaakceptować (wyparta) treść, usunąć ją, ale nie możemy wyeliminować struktury luki czy pęknięcia, która tą treść wytwarza. Możemy również uznać, że to co pacjent chciał powiedzieć, jest dokładnie tym, co faktycznie powiedział: to znaczy, że nie była to ani inna osoba niż matka, ani sama matka, tylko nie-matka albo matka-nie.

Znakomity żart z Ninoçki Ernesta Lubitscha pozwoli nam lepiej rozumieć ten osobliwy obiekt, owa „,matkę-nie”:

Mężczyzna wchodzi do restauracji i zwraca się do kelnera: „Poproszę kawę bez śmietanki”. Kelner odpowiada: „Przepraszam , szanowny panie, ale skończyła nam się śmietanka. Czy może być bez mleka?”.

Żart ten odsłania pewną realność, a nawet pewną prawdę o realności, która wiąże się z tą osobliwą negatywnością wprowadzoną lub odkrytą przez psychoanalizę. Negacja czegoś nie jest czystym brakiem bądź czystym niczym, ani po prostu dopełnieniem tego, co jest negowane. W samym momencie jej wypowiedzenia pozostaje ślad tego, czym nie jest. Jest to wymiar wprowadzony (i umożliwiony) dzięki znaczącemu, choć nie da się go do niego zredukować. Ma on lub może mieć pozytywna, choć widmową jakość, którą najlepiej wyraża formuła „z bez (śmietanki)” jako niesprowadzalna do żadnej z alternatyw (śmietanka/bez śmietanki).

Gdy więc matka pojawia się w tym osobliwym połączeniu z negacją, tj. gdy pojawia się jako „nie-matka”, to oba terminy nieodwracalnie nawzajem się zanieczyszczaja. Tak jakby 
„nie” naznaczało matkę stemplem nieświadomego pragnienia („tak jak made in Germany wytłoczone na przedmiocie”, mówi Freud), natomiast „matka” zanieczyszczała formalna czystość negacji „śladową ilością czegoś” - jak możemy czasami przeczytać na opakowaniach. Mówiąc nieco bardziej szczegółowo: matka, od której zaczynamy (zanim zostanie zanegowana), nie jest tą samą, co matka-obiekt wytworzony przez negację, czyli przez pracę nieświadomości. Ta jest już inną matką, matką - by się tak wyrazić - wywołującą skutki, a nie stanowiąca po prostu element Natury. Dlatego przyznanie analitykowi, że to była twoja matka, ostatecznie wcale mu nie pomaga i dlatego mimo przyznania się w mocy pozostaje esencja wyparcia. Odesłani zostajemy tylko do matki jako czegoś faktycznego, „elementu natury", co nijak nie zbliża nas do wymiaru realnego.

Dochodzimy tym samym do istoty naszej dyskusji, czyli pytania o realizm i realność, które psychoanaliza dzieli z nauką. Można następująco podsumować kluczowy punkt naszych rozważań. Podmiot nieświadomości jest podmiotem (nowoczesnej) nauki w tym sensie, że jest istotowo powiązany z polem, w którym dyskurs wywołuje skutki. Bez tego pola nie ma podmiotu, a na pewno nie ma podmiotu nieświadomości. W ten sposób należałoby rozumieć twierdzenie Lacana, że podmiot jest „odpowiedzią realności”, la réponse du réel. To nie to samo, co być efektem dyskursu albo być dyskursywnie ustanowionym. Podmiot i nieświadomość nie są efektami języka, a tym bardziej nie są bytami lingwistycznymi, należą bowiem do pola realności, to znaczy do pola, które tylko wyłania się wraz z językiem, ale nie sprowadza się do niego (np. jako jego performatywny wytwór). Realność zdefiniowana jest przez fakt, że język wywołuje w niej skutki. Moglibyśmy w związku z tym powiedzieć, że: jeśli nauka wytwarza I działa w polu, w którym dyskurs wywołuje skutki, to psychoanaliza jest nauką o tym osobliwym polu, o zaskakujących sposobach działania tych skutków oraz o specyficznym statusie ontologicznym obiektów, które w nim występują.

Nie powinniśmy jednak przedstawiać konkluzji, pominąwszy wyzwanie wpisane w wyjściowe pytanie Meillassoux, które stawiał zresztą z godną podziwu prostotą i bezpośredniością. A zatem: jak Lacanowski realizm skutków, który wiązać należy z niemożliwością, wpływa na status tak zwanych twierdzeń ancestralnych? Czy zdanie „ziemia powstała 4,5 miliarda lat temu" ma jakikolwiek sens niezależnie od nas, czy odnosi się do określonego przedmiotu, który faktycznie istniał (aczkolwiek według naszych obliczeń opierających się na datowaniu izotopowym) 4,5 miliarda lat temu?

Dlaczego nie mielibyśmy zaryzykować odpowiedzi? Przytoczę w tym celu fascynującą historię na temat skamielin, która może nadać pojęciu praskamieliny zaskakujący Lacanowski zwrot. Meillassoux co prawda nawiązuje w swojej książce do tej historii - jednak w charakterze całkowicie powierzchownej aluzji, która funkcjonuje co najwyżej jako retoryczny argument wykpiwający absurdy korelacjonizmu - przez co zupełnie zapoznany zostaje jej prawdziwy spekulatywny potencjał. 
Stephen Jay Gould (1985) w jednym ze swoich znakomitych esejów zatytułowanym „Adam’s Navel” pisze o zdumiewającej, „niedorzecznej”, choć niezwykle eleganckiej teorii ważnego brytyjskiego przyrodnika Philipa Henry’ego Gosse’a. Ten współczesny Darwinowi badacz opublikował interesująca nas pracę (Omphalos) w 1857 roku, tylko dwa lata przed O powstawaniu gatunków. Największą namiętnością Gosse’a były skamieliny, które badał i opisywał z niezwykłym oddaniem. Powstająca w owym czasie nauka geologii zgromadziła już dowody na bardzo stary wiek ziemi, dosadnie przecząc Księdz̨e Rodzaju (mówiącej w tym kontekście o zaledwie sześciu tysiącach lat). I na tym polegał podstawowy dylemat Gosse’a był on bowiem nie tylko oddanym swej pracy przyrodnikiem, ale także człowiekiem głębokiej wiary. Jego teoria próbowała więc rozwiązać sprzeczność pomiędzy (stosunkowo niedawnym) stworzeniem ex nibilo a rzeczywistym istnieniem znacznie starszych skamielin. Gosse wpadł na sprytne rozwiązanie, zgodnie z którym Bóg faktycznie stworzył świat sześć tysięcy lat temu, ale nie stworzył go jedynie dla przyszłości, lecz także retroaktywnie, „dla przeszłości” - w momencie kreacji ziemi umieścił w niej skamieliny. Nie powinno nam umknąć piękno tego gestu, który wymazuje sam siebie: na użytek badań naukowych Bóg stworzył świat, usuwając z niego ślady stworzenia, a zatem poszlaki swojego własnego istnienia. I chyba nie bez powodu jego teorię nawet bardziej zawzięcie zwalczali teologowie niż naukowcy. Natychmiast wypracowano konsensus, zgodnie z którym Bóg nie mógł „zapisać w kamieniach jednego wielkiego i niepotrzebnego kłamstwa”. Według Goulda większość współczesnych amerykańskich kreacjonistów odrzuca tę teorię równie gwałtownie, ponieważ „imputuje Bogu wątpliwy charakter moralny”.

Z perspektywy omawianej przeze mnie dyskusji w teorii Gosse'a interesujące jest przede wszystkim rozpoznanie niewystarczalności linearnej teorii czasu w kontekście pytania o realność. Nie powinniśmy dać się zwieść aurze dziwaczności otaczającej historię Gosse’a, gdyż ze strukturalnego punktu widzenia jego dylemat jest taki sam jak u Meillassoux. Wystarczy zastapić Boskie stworzenie kreacja autorstwa człowieka (subiektywnie/dyskursywnie konstytuowana przyroda) i stajemy przed zadziwiająco podobnym pytaniem: czy nauka bada tylko coś, co sami już ustanowiliśmy (jako coś zewnętrznego), czy też zewnętrzność ta jest niezależna od nas i istniała już na długo przed nami? Lacanowska odpowiedź byłaby następująca: zewnętrzność jest niezależna, ale staje się taka dopiero w momencie „stworzenia”. Innymi słowy: w momencie pojawienia się - dajmy na to, ex nibilo - czystego znaczącego, a wraz z nim rzeczywistości, w której dyskurs wywołuje skutki, otrzymujemy niezależną od nas fizyczną rzeczywistość (co nie oznacza, że nie mamy na nią żadnego wypływu). I ta niezależność odnosi się oczywiście także do czasu „uprzedniego wobec nas”. Rzeczywistość praskamielin, czyli przedmiotów twierdzeń ancestralnych, nie różni się wcale od rzeczywistości przedmiotów nam współczesnych ponieważ ani jedne, ani drugie nie są korelatami naszego myślenia, będąc za 
to obiektywnymi korelatami cięcia w rzeczywistości jako homogenicznym kontinuum (cięcia nowoczesnej nauki, jak i pojawienia się znaczącego jako takiego). Z tego właśnie powodu teoria Lacana jest „dialektycznie-materialistyczna”: cięcie implikuje spekulatywną tożsamość absolutu i stawania się. Nie są one sobie przeciwstawne, ale powinny być myślane razem. Coś może (z czasem) stać się absolutne (czyli ponadczasowe). Absolut jest jednocześnie konieczny i przygodny: nie ma absolutu bez pęknięcia, w którym konstytuuje się jako absolut (to znaczy jako „konieczna konieczność” - to podwojenie jest właśnie przestrzenią, w której dyskurs wywołuje skutki), ale pęknięcie to jest przygodne.

W przeciwieństwie do tego Meillassoux w swoim geście absolutyzacji przygodności jako jedynej konieczności ostatecznie uprawia nie tyle spekulację, co idealizm: wszystko jest przygodne za wyjątkiem konieczności tej przygodności. Za sprawą takiego twierdzenia Meillassoux w rzeczywistości absolutyzuje nieobecną przyczynę (która jeśli byłaby obecna, ugruntowałaby konieczność istniejących praw). Jego argument jest w tym kontekście dobrze znany: nie ma żadnej wyższej przyczyny czy konieczności, z powodu której prawa przyrody są takie, a nie inne. Mogą więc zmienić się w każdej chwili - przygodnie i bez żadnej racji, czyli ex nibilo (Meillassoux nie rezygnuje z tego określenia). Widzimy jednak, co przez to zachodzi: mamy ateistyczną strukturę, która nie może obejść się bez absolutyzacji nieobecnej Przyczyny gwarantującej w ten sposób przygodność wszystkich praw. Mamy zatem do czynienia z czymś na kształt „Boga ateistów”, tj. Boga, który gwarantuje, że nie ma żadnego Boga. W koncepcji, która próbowaliśmy tu nakreślić z pomoca Lacana, sprawy maja się inaczej. Lacanowski ateizm może być tylko ateizmem braku jakiejkolwiek gwarancji, a dokładniej, braku zewnętrznej (albo meta-) gwarancji: gwarancja zawiera się w tym, co gwarantuje. Nie ma zewnętrznej gwarancji, ale to nie to samo, co brak gwarancji (czy ,absolutu”) w ogóle. Na to właśnie wskazuje pojęcie nie-całości, które się różni od pojęcia konstytutywnego wyjątku: to, co może podważyć jedną i potwierdzić inną dyskursywną teorię, może pochodzić tylko z wnętrza dyskursu. (W nauce oznacza to, że eksperyment może potwierdzić albo zdyskwalifikować określoną konfigurację teoretyczną tylko w jej własnych ramach; eksperyment może potwierdzić albo obalić teorię, tylko jeśli wykonuje się go na jej zasadach; nie ma niczego poza teorią, co mogłoby stanowić dla niej miarę). Zamiast logiki wyjątku i meta-poziomu, który totalizuje pewną „całość” (wszystko jest przygodne, wszystko poza koniecznościa tej przygodności), mamy tutaj do czynienia z logika nie-całości. Aksjomat Lacana, który można by sformułować jako „konieczność jest nie-cała”, nie absolutyzuje przygodności, tylko ustanawia ja jako punkt prawdy absolutnej konieczności w jej stawaniu się konieczną (w jakimś momencie w czasie).

Co już na sam koniec prowadzi nas do jednej istotnej różnicy, która mimo wszystko zachodzi między psychoanalizą i nauką, i jest łączona przez Lacana z kwestia prawdy. W skrócie: nauka nie dostrzega albo nie chce w ogóle uwzględnić faktu, że jednym 
ze skutków dyskursu jest także wymiar prawdy. Prawda jako obiektywny wymiar dyskursu. Nie prawda o danej konfiguracji, lecz prawda jako nieredukowalny element tej konfiguracji, jako istotny produkt uboczny szczeliny zaistniałej w immanencji, która czyni nie-cała, to znaczy sprawia, że immanencja zawiera w samej sobie własne kryterium realności. Jako element danej konfiguracji - tj. element realności - prawda może przemawiać tylko w pierwszej osobie - stąd właśnie wywodzi się Lacanowska idea prozopopei prawdy: „Ja, prawda, przemawiam". To właśnie pole prawdy interesuje psychoanalizę i tu zaczyna się inna opowieść o jej realizmie, gdzie do gry wkracza już pewien dystans wobec nauki. Nie byłoby błędem określenie tego dystansu mianem politycznego, albowiem wraz z wymiarem prawdy z konieczności pojawia się wymiar konfliktu (zob. Lacan 2006a, 38). 


\section{Wykaz literatury}

Chiesa, Lorenzo. 2010. "Hyperstructuralism's Necessity of Contingency". Journal of the Jan van Eyck Circle for Lacanian Ideology Critique 3.

Freud, Zygmunt. 2009. Psychologia nieświadomości. Tłum. Robert Reszke. Warszawa:

Wydawnictwo KR.

Gould, Stephen Jay. 1985. “Adam’s Navel”. W Gould, Stephen Jay. Flamingo's Smile.

Harmondsworth: Penguin Books

Lacan, Jacques. 1990. Television: A Challenge to the Psychoanalytic Establishement, New YorkLondon: Norton \& Company.

Lacan, Jacques. 2006a. Le séminaire, livre XVI: D'un autre à l'Autre. Paris: Seuil.

Lacan, Jacques. 2006b. Le séminaire, livre XVIII: D'un discours qui ne serait pas du semblant. Paris: Seuil.

Malabou, Catherine. 2007. Les nouveaux blesses. Paris: Bayard.

Meillassoux, Quentin. 2015. Po skończoności. Tłum. Piotr Herbich. Warszawa: Fundacja Augusta hr. Cieszkowskiego.

Milner, Jean-Claude. 2008. Le périple structural. Lagrasse: Verdier.

Žižek, Slavoj. 2010. Living in the End Times. London-New York: Verso. 
Alenka Zupančič - profesor w Instytucie Filozofii Słoweńskiej Akademii Nauk i Sztuk oraz profesor wizytujący w European Graduate School (EGS), Saas-Fee w Szwajcarii. W swoich badaniach zajmuje się głownie związkami psychoanalizy i filozofii. Jest autorka licznych artykułów i kilku książek, między innymi, Kant and Lacan (Verso 2000), The Shortest Shadow: Nietzsche's Philosophy of the Two (MIT Press 2003), The Odd One In: On Comedy (MIT Press 2008), czy Why Psychoanalysis: Three Interventions (Aarhus University Press 2008).

\section{DANE ADRESOWE:}

Institute of Philosophy

Research Center of the Slovenian Academy of Sciences and Arts

Novi $\operatorname{trg} 2$,

SI-1000 Ljubljana

Słowenia

EMAIL: alenka.zupancic@guest.arnes.si

CYTOWANIE: Zupančič, Alenka. 2018. „Realizm w psychoanalizie.“ Praktyka Teoretycz̧na 2(28): 107-123.

DOI: $10.14746 /$ prt.2018.2.5

\section{AUTHOR: Alenka Zupančič}

TITLE: Realism in Psychoanalysis

ABSTRACT: Many recent philosophical discussions have been marked by the rather stunning re-launching of the question of realism, triggered by Quentin Meillassoux's book After finitude (Après la finitude, 2006), and followed by a wider, albeit less homogeneous, movement named 'speculative realism'. This paper raises the question of whether the conceptual field of Lacanian psychoanalysis is concerned with this debate, and if so how. The central argument scrutinizes the status of the 'real' in science, and its implications for psychoanalysis in view of the Lacanian identification of the subject of the unconscious with the subject of (Galilean) science. Taking seriously Lacan's claim that 'If I am anything, it is clear that I'm not a nominalist', the present paper aims at sketching out a psychoanalytic version of realism.

KEYWORDS: discourse, impossible, Lacan, Real, science, truth. 